Tersedia online di: http://ejournal-balitbang.kkp.go.id/index.php/jra

\title{
PENGARUH PEMBERIAN HORMON PERTUMBUHAN REKOMBINAN DENGAN METODE YANG BERBEDA TERHADAP PERTUMBUHAN BENIH IKAN BOTIA (Chromobotia macracanthus)
}

\author{
Asep Permana**\#, Alimuddin ${ }^{* *}$, Wartono Hadie ${ }^{* * *}$, Agus Priyadi*), dan Rendy Ginanjar ${ }^{*}$ \\ *) Balai Riset Budidaya Ikan Hias \\ Jl. Perikanan No. 13, Pancoran Mas, Depok 16364 \\ *) Departmen Budidaya Perairan, Fakultas Perikanan dan IImu Kelautan, Institut Pertanian Bogor \\ Kampus IPB Darmaga, Jl. Agatis, Babakan, Dramaga, Bogor, Jawa Barat 16680 \\ **) Pusat Riset Perikanan \\ Jl. Pasir Putih II, Ancol Timur, Jakarta Utara 14430
}

(Naskah diterima: 15 Maret 2018; Revisi final: 16 Agustus 2018; Disetujui publikasi: 16 Agustus 2018)

\begin{abstract}
ABSTRAK
Pertumbuhan ikan botia tergolong lambat, memerlukan waktu sekitar enam bulan untuk mencapai ukuran komersial (panjang total 4-5 cm). Penelitian ini bertujuan untuk mengevaluasi respons pertumbuhan benih ikan botia yang diberi hormon pertumbuhan ikan kerapu ( $\mathrm{rEIGH}$ ) melalui tiga metode yaitu: perendaman, oral, dan kombinasi perendaman dan oral. Penelitian menggunakan rancangan acak lengkap dan setiap perlakuan diulang tiga kali. Dosis rEIGH melalui perendaman yaitu 1,2 mg/L diberikan pada larva umur tujuh hari, sedangkan dosis secara oral yaitu $30 \mathrm{mg} / \mathrm{kg}$ pakan dan diberikan pada benih umur tiga bulan. Ikan dipelihara dalam akuarium sistem resirkulasi $(80 \mathrm{~cm}$ x $40 \mathrm{~cm}$ x $25 \mathrm{~cm}$ ) dengan kepadatan 5 ekor/L selama pemeliharaan tiga bulan pertama dan 1 ekor/L selama pemeliharaan periode tiga bulan kedua. Hasil penelitian menunjukkan bahwa perlakuan kombinasi perendaman dan oral memberikan pertumbuhan yang lebih tinggi sebesar 12,04\% dibandingkan kontrol. Perlakuan ini juga meningkatkan level ekspresi insulin-like growth factor-1/ IGF-1 sebesar 29,37\% dibandingkan kontrol.
\end{abstract}

\section{KATA KUNCl: recombinant growth hormone; metode pemberian hormon; Chromobotia macracanthus \\ ABSTRACT: The effects of using recombinant growth hormone on the growth of Clown Loach (Chromobotia macracanthus) juveniles with different methods of administration. By: Asep Permana, Alimuddin, Wartono Hadie, Agus Priyadi, and Rendy Ginanjar}

\begin{abstract}
The growth of Clown Loach is slow. It takes about six months to reach the market size (4-5 cm total body length). This study aimed to evaluate the growth response of Clown Loach treated with recombinant giant grouper growth hormone (rEIGH) delivered by three different methods: immersion, oral, and the combination of immersion and oral. A completely randomized design was used as the experimental design and each treatment was replicated three times. The immersion method used rEIGH dose of $1.2 \mathrm{mg} / \mathrm{L}$ on seven-day-old larvae, while oral treatment used $30 \mathrm{mg} \mathrm{rEIGH} / \mathrm{kg}$ feed on the three-month-old juvenile. The fish were reared in a closed recirculation tank $(80 \mathrm{~cm} \times 40 \mathrm{~cm} \times 25 \mathrm{~cm})$ at a density of 5 fish/L for the first three months, and 1 fish/L for the second three months of rearing period. The result showed that the combination of immersion and oral treatments produced a higher growth rate of $12.04 \%$ compared to control treatment. Those treatments also increased insulin-like growth factor-1/IGF-1 expression level about 29.37\%compared to the control.
\end{abstract}

KEYWORDS: recombinant growth hormone; delivery method; clownloach; Chromobotia macracanthus

\footnotetext{
\# Korespondensi: Balai Riset Budidaya Ikan Hias. Jl. Perikanan

No. 13, Pancoran Mas, Depok 16364, Indonesia.

Tel. + 62217520482

E-mail: asep_aa37@yahoo.co.id
} 


\section{PENDAHULUAN}

Pemberian hormon pertumbuhan rekombinan, terutama pada ikan konsumsi, dilaporkan efektif untuk meningkatkan laju pertumbuhan ikan. Pada ikan hias, efektivitas pemberian rGH telah dilaporkan pada ikan koki mampu meningkatkan bobot sampai 3,1 kali dibandingkan control (Promdonkoy et al., 2004; Acosta et al., 2009). Pada ikan manvish (Pterophyllum scalare) mampu meningkatkan bobot sampai 1,6 kali dibandingkan control (Acosta et al., 2009). Beberapa hormon pertumbuhan ikan sudah berhasil diproduksi, di antaranya rGH dari giant catfish (Promdonkoy et al., 2004), rGH dari ikan salmon (Moriyama \& Kawauchi, 1990), rGH dari tilapia (Acosta et al., 2007), dan rGH dari ikan gurami dan ikan kerapu kertang (Alimuddin et al., 2010).

Perbandingan produksi protein dari tiga jenis hormon pertumbuhan rekombinan yang berasal dari ikan mas, gurame, dan kerapu kertang menunjukkan bahwa hormon pertumbuhan rekombinan dari ikan kerapu kertang (rEIGH) paling banyak digunakan karena tingkat produksi protein lebih tinggi dibandingkan dengan hormon pertumbuhan dari ikan mas (rCcGH) dan ikan gurami (rOgGH) (Irmawati et al., 2012). Selain itu, bioaktivitas rEIGH dalam merangsang pertumbuhan pada ikan nila lebih baik daripada rCcGH dan rOgGH (Alimuddin et al., 2010).

Hormon pertumbuhan rekombinan dapat diaplikasikan dengan cara injeksi (Promdonkoy et al., 2004), secara oral melalui pakan (Hardiantho et al., 2012), melalui perendaman (Acosta et al., 2007), dan kombinasi antara perendaman dan oral (Handoyo, 2012). Aminah (2012) melaporkan bahwa aplikasi rEIGH pada benih ikan sidat melalui perendaman selama dua jam dengan dosis $3 \mathrm{mg} / \mathrm{L}$, dapat meningkatkan biomassa sebesar 28\%dan sintasan sebesar 15,2\%lebih tinggi dibandingkan kontrol. Lebih lanjut, perendaman benih ikan sidat dalam air yang mengandung rEIGH selama dua jam dengan dosis $12 \mathrm{mg} / \mathrm{L}$ dapat meningkatkan pertumbuhan sebesar 37,4\%lebih tinggi dibandingkan kontrol (Handoyo et al., 2012). Sementara itu, perendaman udang vaname stadia PL2 dalam air yang mengandung rEIGH dosis $15 \mathrm{mg} / \mathrm{L}$ selama tiga jam dapat meningkatkan bobot sebesar $109,9 \%$ panjang sebesar $26,0 \%$ dan biomassa sebesar $66,0 \%$ lebih tinggi dibandingkan kontrol (Subaidah et al., 2012).

Budidaya ikan botia di luar habitatnya telah sukses dilakukan di Balai Penelitian dan Pengembangan Budidaya Ikan Hias, Depok. Permasalahan utama dalam budidaya ikan botia yaitu pertumbuhan yang lambat, diperlukan waktu sekitar enam bulan untuk mencapai (panjang total $4-5 \mathrm{~cm}$ ) atau ukuran komersial (Permana et al., 2011). Berdasarkan hal ini, penelitian aplikasi pemberian rGH melalui kombinasi perendaman pada stadia larva dan secara oral melalui pakan pada stadia benih dilakukan dengan tujuan menguji respons pertumbuhan benih ikan botia yang dimediasi oleh IGF-1 dalam hati ikan botia. Hasil akhir yang diharapkan adalah ikan botia yang diberikan rGH melalui metode yang berbeda dapat tumbuh cepat sehingga dapat mempersingkat masa pemeliharaan.

\section{BAHAN DAN METODE}

\section{Waktu dan Tempat Penelitian}

Penelitian dilaksanakan di Balai Penelitian dan Pengembangan Budidaya Ikan Hias (BPPBIH), Depok pada bulan Juli 2014 sampai dengan Desember 2014.

\section{Prosedur Perendaman Larva dalam rEIGH}

Larva ikan botia yang digunakan dalam penelitian ini adalah hasil budidaya dari BPPBIH Depok, berukuran panjang $0,57 \mathrm{~cm}$ dan bobot $0,0019 \mathrm{~g}$ yang berasal dari satu induk. Larva diberikan perlakuan kejut salinitas $\mathrm{NaCl} 20 \mathrm{~g} / \mathrm{L}$ selama satu menit untuk memaksimalkan proses osmoregulasi sebagai jalan rGH masuk ke dalam tubuh ikan, kemudian direndam selama satu jam dalam air mengandung larutan rEIGH (rEIGH dosis $1,2 \mathrm{mg} / \mathrm{L}+\mathrm{NaCl} 3 \mathrm{~g} / \mathrm{L}+\mathrm{BSA} 100 \mathrm{~mL} / \mathrm{L})$ di dalam baskom plastik yang berisi $1 \mathrm{~L}$ air.

\section{Prosedur Pencampuran rEIGH ke Pakan Bloodworm}

Prosedur pencampuran hormon pertumbuhan rekombinan pada bloodworm mengikuti/modifikasi dari Hardiantho et al. (2012). bloodworm beku dicairkan dan ditiriskan. Hormon rekombinan rEIGH dengan dosis $30 \mathrm{mg} / \mathrm{kg}$ dilarutkan dalam $10 \mathrm{~mL}$ phosphate buffer saline (PBS). Larutan rEIGH diberi binder berupa kuning telur $0,13 \mathrm{mg} / \mathrm{mL}$ dan disemprotkan pada bloodworm. Bloodworm yang telah disemprot rEIGH dibiarkan selama 5-10 menit sebelum diberikan ke benih ikan botia sesuai perlakuan. Bloodworm yang mengandung rEIGH diberikan dua kali seminggu (tiga kali sehari) dan disiapkan setiap akan diberikan ke ikan. Pakan diberikan secara ad satiation.

\section{Prosedur Pemeliharaan dan Rancangan Perlakuan}

Ikan dipelihara dalam akuarium ukuran $80 \mathrm{~cm} \times 40$ $\mathrm{cm} \times 25 \mathrm{~cm}$ dengan sistem resirkulasi dan diberi pakan berupa naupli Artemia, dan bloodworm. Ikan dipelihara dengan padat tebar yang sama, yaitu 5 ekor/L (pada pemeliharaan 1-3 bulan) dan 1 ekor/L (pada pemeliharaan 4-6 bulan). Penelitian menggunakan rancangan acak lengkap dan setiap perlakuan diulang 
tiga kali. Perlakuan yang diujikan adalah: 1) kontrol (A), ikan tidak diberi rEIGH; 2) perendaman (B), ikan diberi rEIGH melalui perendaman; 3) oral (C), ikan diberi rEIGH melalui pakan; 4) perendaman dan oral (D), ikan diberi rEIGH melalui perendaman dan oral.

\section{Parameter yang Diamati}

Parameter yang diamati meliputi pertumbuhan, sintasan, dan ekspresi gen insulin-like growth factor-1 (IGF-1). Pertumbuhan yang diamati hanya terkait panjang saja, dikarenakan untuk ikan hias parameter panjang lebih dijadikan patokan bagi ukuran jual di pasaran.

Laju pertumbuhan harian panjang (LPHp) dihitung berdasarkan formula dari Effendie (1997). LPHp $=[($ In $\left.\left.\mathrm{P}_{\mathrm{t}}-\ln \mathrm{P}_{0}\right) / \mathrm{t} \times 100\right]$; $\mathrm{Pt}=$ rerata panjang total tubuh pada akhir penelitian $(\mathrm{mm}), \mathrm{P}_{0}=$ rerata panjang total tubuh di awal penelitian ( $\mathrm{mm}), \mathrm{t}=$ lama waktu penelitian (hari).

Sintasan ikan merupakan persentase jumlah ikan yang hidup pada akhir penelitian dibandingkan dengan jumlah ikan pada saat tebar Effendie (1997).

Analisis ekspresi gen IGF-1 dilakukan untuk menjelaskan mekanisme yang melibatkan rGH dalam induksi pertumbuhan ikan. IGF-1 diekspresikan di hati. Jaringan hati ikan botia dari perlakuan terbaik dan kontrol diambil secara acak pada akhir penelitian masing-masing sebanyak tiga ekor. RNA total diekstraksi dari jaringan hati menggunakan tri-reagent kit (M olecular Research Center). Sintesis cDNA dilakukan menggunakan Transcriptor First Strand cDNA Synthesis Kit (Roche) dengan konsentrasi total RNA $1 \mu \mathrm{g}$ tiap sampel. Ekspresi IGF-1 ikan botia dianalisis menggunakan metode RT-PCR menggunakan primer forward IGF-1 (5'-ACC ATG CGC TGT CTC CCG AGT ACC-3') dan reverse IGF-1 (5'-CAC ACA AAC TGC AGC GTG TCT ACA AGC TCC-3') (Hardiantho et al., 2012). Panjang gen target IGF-1 sekitar 150 bp. PCR dilakukan menggunakan kit Dream Taq Green PCR Master M ix (2X) Thermo Scientific. Komposisi pereaksi terdiri atas: 12,5 $\mu \mathrm{L}$ master mix, primer forward $1 \mu \mathrm{L}$ dan reverse $1 \mu \mathrm{L}$ (20 mol), cDNA $2 \mu \mathrm{L}$, dan nuclease free water sampai total volume reaksi $25 \mu \mathrm{L}$. Proses PCR IGF-1 dilakukan dengan program: denaturasi awal pada suhu $95^{\circ} \mathrm{C}$ selama 15 menit, diikuti oleh 35 siklus amplifikasi pada denaturasi $94^{\circ} \mathrm{C}$ selama 20 detik, annealing pada suhu $65^{\circ} \mathrm{C}$ selama 30 detik, dan ekstensi pada suhu $72^{\circ} \mathrm{C}$ selama 30 detik, serta ekstensi akhir pada suhu $72^{\circ} \mathrm{C}$ selama 10 menit kemudian pengkondisian akhir pada suhu $4^{\circ} \mathrm{C}$. Sebagai kontrol internal digunakan gen â-aktin universal-2 menggunakan primer forward (5'TAT GAA GGT TAT GCT CTG CCC-3') dan reverse (5'CAT ACC CAG GAA AGA TGG CTG-3'). Primer tersebut disusun menggunakan program GENETIX versi 7 dengan panjang gen target â-aktin universal-2 sekitar 300 bp. Proses PCR â-aktin dilakukan dengan program: denaturasi awal pada suhu $94^{\circ} \mathrm{C}$ selama tiga menit, diikuti oleh 30 siklus amplifikasi pada denaturasi $94^{\circ} \mathrm{C}$ selama 30 detik, annealing pada suhu $58^{\circ} \mathrm{C}$ selama 30 detik, dan ekstensi pada suhu $72^{\circ} \mathrm{C}$ selama 30 detik, serta ekstensi akhir pada suhu $72^{\circ} \mathrm{C}$ selama tiga menit kemudian pengondisian akhir pada suhu $4^{\circ} \mathrm{C}$. Analisis ekspresi gen dilakukan secara semi-kuantitatif, yaitu dengan membandingkan tingkat ekspresi gen IGF-1 dan â-aktin. Kuantifikasi ketebalan pita pada gen IGF1 dan â-aktin dilakukan menggunakan program Alpha View SA untuk membandingkan antara perlakuan terbaik dengan kontrol.

\section{Analisis Data}

Panjang akhir, laju pertumbuhan harian panjang, serta sintasan dianalisis menggunakan uji sidik ragam (ANOVA) dan jika terdapat perbedaan nyata $(P<0,05)$, maka dilanjutkan dengan uji Tukey dengan bantuan piranti lunak SPSS versi 17. Ekspresi gen IGF-1 dianalisis secara deskriptif.

\section{HASIL DAN BAHASAN}

\section{Pertumbuhan dan Sintasan}

Penelitian uji bioaktivitas pemberian rEIGH melalui kombinasi perendaman pada stadia larva dan oral pada stadia benih didapatkan hasil seperti terlihat pada Tabel 1. Respons pertumbuhan tertinggi didapatkan pada perlakuan $D$ yaitu kombinasi antara perendaman dan oral. Perlakuan tersebut menghasilkan panjang akhir yang nilainya $12,04 \%$ lebih tinggi dibandingkan kontrol $(P<0,05)$, dan laju pertumbuhan harian panjang $5,83 \%$ lebih tinggi dibandingkan kontrol $(\mathrm{P}<0,05)$. Perlakuan $C$ yaitu perlakuan pemberian rEIGH secara oral memberikan respons pertumbuhan lebih baik dibandingkan kontrol. Perlakuan tersebut menghasilkan panjang akhir yang nilainya 5,87\%lebih tinggi dibandingkan kontrol $(P<0,05)$, dan laju pertumbuhan harian panjang 2,92\% lebih tinggi dibandingkan kontrol $(P<0,05)$. Respons pertumbuhan terendah didapat pada perlakuan B yaitu perlakuan pemberian rEIGH secara perendaman. Perlakuan tersebut menghasilkan panjang akhir yang nilainya 3,96\%lebih tinggi dibandingkan kontrol $(P>0,05)$; dan laju pertumbuhan harian panjang 1,97\%lebih tinggi dibandingkan kontrol $(P>0,05)$. Hal ini juga menunjukkan bahwa pemberian rEIGH lebih efektif jika diberikan secara berulang dan dalam dosis yang tepat. Sementara itu, sintasan ikan pada semua perlakuan tidak berbeda secara signifikan $(P>0,05)$. 
Tabel 1. Panjang akhir, laju pertumbuhan harian panjang (LPHp), dan sintasan benih ikan botia pada kontrol dan perlakuan pemberian rEIGH melalui kombinasi perendaman pada stadia larva dan oral pada stadia benih

Tabel 1. Final length, length daily growth rate (LPHp), and survival rate of Clown Loach juveniles on control and rEIGH delivered through combination methods of immersion at larval stadium and oral at juvenile stadium

\begin{tabular}{lcccc}
\hline & \multicolumn{4}{c}{ Perlakuan (Treatments) } \\
\cline { 2 - 5 } \multicolumn{1}{c}{\begin{tabular}{c} 
Parameter \\
\cline { 2 - 5 }
\end{tabular}} & A & B & C & D \\
\cline { 2 - 5 } & $\begin{array}{c}\text { Kontrol } \\
\text { Control }\end{array}$ & $\begin{array}{c}\text { Perendaman } \\
\text { Immersion }\end{array}$ & $\begin{array}{c}\text { Oral } \\
\text { Orally }\end{array}$ & $\begin{array}{c}\text { Perendaman dan oral } \\
\text { Immersion and orally }\end{array}$ \\
\hline $\begin{array}{l}\text { Panjang akhir }(\mathrm{mm}) \\
\text { Final length }(\mathrm{mm})\end{array}$ & $40.37 \pm 1.35^{\mathrm{a}}$ & $41.97 \pm 0.61^{\mathrm{ab}}$ & $42.74 \pm 0.62^{\mathrm{b}}$ & $45.23 \pm 0.76^{\mathrm{c}}$ \\
$\begin{array}{l}\text { LPHp (\%) } \\
\text { Sintasan (\%) }\end{array}$ & $1.165 \pm 0.020^{\mathrm{a}}$ & $1.188 \pm 0.009^{\mathrm{ab}}$ & $1.199 \pm 0.009^{\mathrm{b}}$ & $1.233 \pm 0.010^{\mathrm{c}}$ \\
Sunvival rate (\%) & $86.00 \pm 6.00^{\mathrm{a}}$ & $90.00 \pm 3.00^{\mathrm{a}}$ & $89.33 \pm 6.11^{\mathrm{a}}$ & $88.67 \pm 2.52^{\mathrm{a}}$ \\
\hline
\end{tabular}

Keterangan: Huruf superskrip yang berbeda pada baris yang sama adalah berbeda nyata $(P<0,05)$

Note: Different superscript letters in the same row are statistically different $(P<0.05)$

Ukuran ikan tiap perlakuan pada akhir penelitian (setelah umur enam bulan) dapat dilihat pada Gambar 1.

Peningkatan pertumbuhan melalui pemberian rGH pada ikan konsumsi sudah banyak dilaporkan. Metode pemberiannya juga beragam (injeksi, perendaman, dan oral). Pada ikan hias, efektivitas pemberian rGH telah dilaporkan pada ikan koki melalui injeksi dapat meningkatkan pertumbuhan bobot hingga 3,1 kali dibandingkan kontrol (Promdonkoy et al., 2004), pada ikan manvish melalui perendaman dapat meningkatkan pertumbuhan bobot hingga 1,6 kali dibandingkan kontrol (Acosta et al., 2009). Pemberian rGH pada penelitian-penelitian sebelumnya biasanya hanya menggunakan satu metode saja. Pemberian melalui kombinasi antar metode sudah dilakukan pada ikan sidat, yaitu melalui kombinasi perendaman dan oral. Hasil penelitian menunjukkan bahwa kombinasi keduanya lebih baik dibandingkan hanya melalui perendaman atau oral saja (Handoyo, 2012).
A

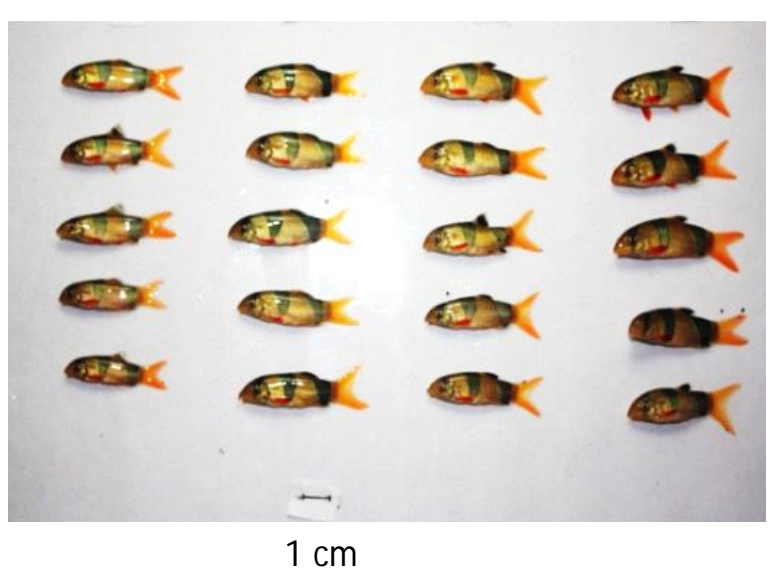

$1 \mathrm{~cm}$
C D

(1)

Gambar 1. Ikan botia umur enam bulan hasil percobaan perlakuan pemberian $\mathrm{rEIGH}$ dengan metode berbeda: A) kontrol; B) perendaman; C) oral; D) perendaman + oral.

Figure1. Six months old Clown Loach fish produced from rEIGH delivered through different methods: A) control; B) immersion only; C) orally at feed only; D) immersion + orally at feed. 
Pada penelitian ini, respons perlakuan pemberian rGH melalui perendaman saja pada stadia larva hasilnya menunjukkan tidak berbeda nyata dengan control setelah pemeliharaan selama enam bulan. Hal ini menunjukkan bahwa pemberian rGH hanya sekali di awal pemeliharaan yaitu pada saat larva kurang efektif untuk meningkatkan pertumbuhan. Perlu adanya pengulangan dalam pemberian $r G H$ untuk memaksimalkan pertumbuhan. Hasil ini diperkuat dengan data level IGF-1 seperti dilaporkan oleh Irmawati et al. (2012) yang menyatakan bahwa level IGF-1 larva ikan gurami mengalami peningkatan setelah diredam dalam larutan yang mengandung $\mathrm{rGH}$, dan puncaknya pada jam ke-24, dan kemudian menurun sampai kembali ke kondisi semula pada jam ke-48.

Perlakuan pemberian rGH melalui oral lewat pakan bloodworm pada stadia benih memberikan respons yang berbeda nyata dibandingkan kontrol tetapi tidak berbeda nyata dengan perlakuan pemberian $\mathrm{rGH}$ melalui perendaman pada stadia larva terhadap pertumbuhan. Hasil ini juga menunjukkan belum optimalnya pemberian rGH melalui pemberian secara oral saja. Pemberian secara berulang perlu dilakukan untuk meningkatkan pertumbuhan lebih maksimal. Hasil ini juga diperkuat dengan data level IGF-1 ikan sidat tujuh hari setelah diberhentikan pemberian rGH secara oral antara ikan sidat perlakuan dan kontrol (0 jam) menunjukkan level yang sama, dan meningkat 24 jam setelah pemberian pakan yang mengandung rEIGH (Handoyo, 2012).

Perlakuan kombinasi pemberian rGH melalui perendaman pada stadia larva dan dilanjutkan secara oral melalui pakan alami bloodworm pada stadia benih terbukti menghasilkan performa terbaik dibandingkan kontrol dan kedua metode yang lain (melalui perendaman saja atau oral saja). Hasil ini membuktikan bahwa pemberian rGH pada ikan perlu dilakukan secara berulang untuk mendapatkan hasil yang lebih maksimal seperti halnya pada ikan sidat (Handoyo, 2012). Pada ikan rainbow, Haghighi et al. (2011) menyatakan bahwa hormon pertumbuhan rekombinan yang diberikan secara oral tidak terdeteksi lagi dalam darah, saluran pencernaan, dan otot pada 90 menit setelah pemberian.

Penjelasan mengenai mekanisme masuknya rGH dalam tubuh ikan ketika diberikan melalui perendaman dan oral (melalui proses penyalutan) masih belum jelas. Pada penelitian sebelumnya dijelaskan bahwa gonadotropin releasing hormone mampu terserap oleh insang ikan mas koki, dan pada percobaan BSA yang diberi label radioaktif mampu melewati insang dan lapisan epidermis ikan rainbow trout setelah direndam dalam larutan yang berisi BSA tersebut. Ukuran partikel BSA
(66,5 kDA) lebih besar dibandingkan dengan rGH (20$25 \mathrm{kDa}$ ) (Moriyama \& Kawauchi, 1990; Carpio et al., 2007). Dengan demikian, diduga bahwa rGH diserap oleh tubuh ikan melalui insang dan lapisan epidermis. Selanjutnya, penyerapan rGH pada pemberian secara oral adalah melalui usus (Habibi et al., 2003).

Sintasan benih ikan botia yang diberi rEIGH melalui perendaman, oral, dan kombinasi perendaman dan oral tidak berbeda secara signifikan dengan kontrol $(P>0,05)$. Jika dilihat dari nilai sintasannya, semuanya tergolong tinggi yaitu > 86\% Kondisi ini dikarenakan selama penelitian tidak ada serangan penyakit. Terkait pengaruh rEIGH terhadap sintasan, beberapa penelitian sebelumnya dilaporkan bahwa sintasan ikan yang diberi rEIGH lebih tinggi daripada kontrol (Handoyo, 2012; Hardiantho et al., 2012). Pada faktanya, peningkatan daya tahan ikan yang telah diberi rGH terhadap infeksi penyakit karena GH mampu meningkatkan sel-sel yang berkompeten dalam sistem kekebalan tubuh (Kelley, 1989; Gala, 1991; Sakai et al., 1997; Harris \& Bird, 2000).

\section{Ekspresi Gen IGF-1}

Keberadaan gen IGF-1 pada benih ikan botia yang diberi perlakuan D dapat dilihat pada Gambar 2. Hasil penelitian menunjukkan bahwa level ekspresi IGF-1 pada ikan perlakuan $D(2,91)$ meningkat sebesar $29,38 \%$ lebih tinggi dibandingkan kontrol $(2,25)$ (Gambar 3). Tingginya tingkat ekspresi IGF-1 akibat pemberian rEIGH menunjukkan bahwa aktivitas rEIGH melibatkan IGF-1 yang telah dielektroporasi (Gambar 3).

Peran GH dalam memengaruhi pertumbuhan, penelitiannya sudah banyak dilakukan. Perkembangan terakhir diketahui adanya mekanisme pengaturan $\mathrm{GH}$ secara langsung dan tidak langsung dalam memacu pertumbuhan. M ekanisme secara langsung adalah $\mathrm{GH}$ akan langsung memengaruhi pertumbuhan organ target (tanpa perantara IGF-1 di dalam hati). Mekanisme tidak langsung adalah mekanisme GH dalam memengaruhi pertumbuhan yang dimediasi oleh IGF1 dalam hati ikan. Pada penelitian ini ekspresi IGF-1 lebih tinggi daripada kontrol. Hal tersebut mengindikasikan bahwa induksi pertumbuhan ikan botia akibat pemberian rEIGH dimediasi oleh IGF-1. Hasil yang sama juga telah dilaporkan pada ikan yellow tail (Seriola quinqueradiata), perlakuan rGH dapat meningkatkan IGF-1 dalam hati (Pedroso et al., 2009). Pemberian GH secara oral pada ikan salmon juga meningkatkan plasma IGF-1 sampai puncaknya pada 24 jam setelah pemberian. Level plasma IGF masih tinggi sampai tiga hari, kemudian kembali pada level normal (M oriyama et al., 2000). Mekanisme rGH dalam meningkatkan pertumbuhan melibatkan beberapa 


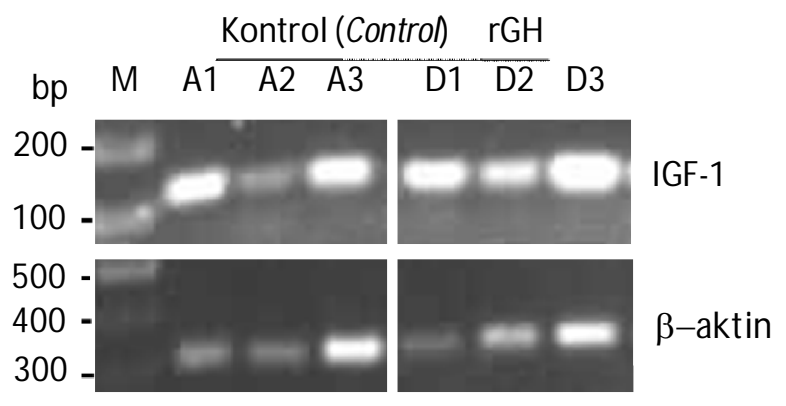

Gambar 2. Amplifikasi keberadaan gen IGF-1dan gen $\beta$-aktin pada organ hati benih ikan botia ( $M=$ marker, $(A 1-A 3)=$ kontrol, (D1-D3) = kombinasi pemberian rGH melalui perendaman dan oral).

Figure 2. Amplification of IGF-1 gene and $\beta$-actin gene presence in liver organs of clown loach juvenile $(M=$ marker, $(A 1-A 3)=$ control, (D1-D3) = combination of $\mathrm{rGH}$ administration through immersion and oral).

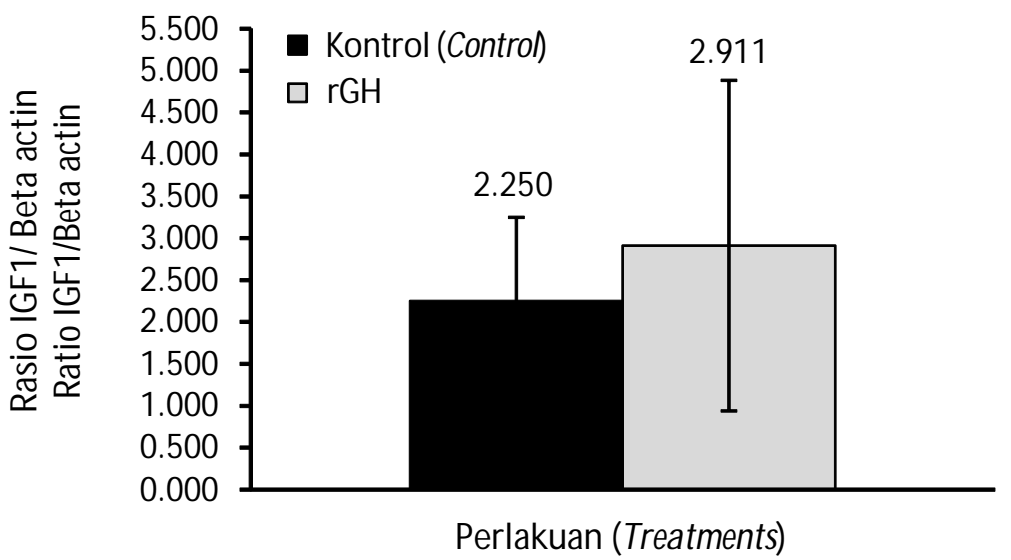

Gambar 3. Tingkat ekspresi mRNA gen insulin-like growth factor I (IGF-1) pada perlakuan kontrol (bar hitam) dan perlakuan hormon pertumbuhan rekombinan ( $\mathrm{rGH}$, bar putih) dengan kombinasi perendaman dosis $1,2 \mathrm{mg} / \mathrm{L}$ dan oral melalui pakan dosis $30 \mathrm{mg} / \mathrm{kg}$ pakan. Ekspresi mRNA gen â-aktin digunakan sebagai kontrol internal loading RNA total dalam sintesis CDNA.

Figure 3. mRNA gen insulin-like growth factor I (IGF-1) exspresion level at control treatment (black bar) and recombinant growth hormone ( $\mathrm{rGH}$ ) treatment (white bar) with combination treatment immersion at $1.2 \mathrm{mg} / \mathrm{L}$ dose and orally at $30 \mathrm{mg} / \mathrm{kg}$ feed. mRNA gen â-aktin exspresion used as internal control on total internal loading RNA at CDNA synthesis.

faktor yang berperan yaitu: reseptor $\mathrm{GH}(\mathrm{GHr}), \mathrm{GH}$ binding proteins (GHBPs), IGF binding proteins (IGFBPs), dan reseptor IGF. GHr berfungsi dalam menangkap sinyal GH yang disekresikan oleh pituitari, GHBPs berfungsi dalam melindungi, dan pengangkutan $\mathrm{GH}$ dari pituitari di dalam darah. IGFBPs berfungsi dalam melindungi dan mengangkut IGF-1 di dalam darah menuju ke organ target. Reseptor IGF-1 berfungsi untuk menangkap sinyal IGF-1 dalam organ-organ yang menjadi target (Sanchez \& Pierre, 1999; Moriyama et al., 2000; Wong et al., 2006; Debnanth, 2010). 


\section{KESIMPULAN}

Pemberian rEIGH melalui perendaman atau oral tidak efektif dalam meningkatkan pertumbuhan ikan botia. Pemberian rEIGH secara kombinasi melalui metode perendaman pada stadia larva dan oral pada stadia benih memberikan efek signifikan terhadap laju pertumbuhan yaitu $12,04 \%$ lebih tinggi dibandingkan kontrol. Peningkatan pertumbuhan ikan botia seiring dengan meningkatnya level ekspresi gen IGF-I yaitu sebesar $29,37 \%$ dibandingkan kontrol. Pemberian rEIGH secara oral, perendaman ataupun kombinasi keduanya tidak memberikan efek signifikan terhadap sintasan.

\section{UCAPAN TERIMA KASIH}

Penelitian ini merupakan kegiatan yang didanai oleh DIPA-APBN Tahun 2014. Terima kasih kami ucapkan kepada para teknisi Hanggar Balai Penelitian dan Pengembangan Budidaya Ikan Hias (BPPBIH) Depok yang telah membantu pelaksanaan penelitian ini (Rona, Rinal, Santi, Hasan, dan Angga G.) serta tim peneliti ikan botia atas kerja samanya.

\section{DAFTAR ACUAN}

Acosta, J., Morales, R., Morales, A., Alonso, M., \& Estrasa, M.P. (2007). Pichia pastoris expressing recombinant tilapia growth hormone accelerates the growth of tilapia. Biotechnol Lett., 29, 1671-1676.

Acosta, J., Estrada, M.P., Carpio, Y., Ruiz, O., Morales, R., Martinez, E., Valdes, J., Borroto, C., Besada, V., Sanchez, A., \& Herera, F. (2009). Tilapia somatotropin polypeptides: potent enhancers of fish growth and innate immunity. Biotechnologia Aplicada, 26, 267-272.

Alimuddin, Lesmana, I., Sudrajat, A.O., Carman, 0., \& Faisal, I. (2010). Production and bioactivity potential of three recombinant growth hormones of farmed fish. Indonesian Aquaculture Journal, 5(1), 11-16.

Aminah. (2012). Aplication of giant grouper recombinant hormone on glass eel by immersed at different doses. Skripsi. Bogor Agricultural University. Bogor.

Carpio, Y., Leon, K., Acosta, J., M orales, R., \& Estrada, M.P. (2007). Recombinant tilapia neuropeptide $Y$ promotes growth and antioxidant defenses in African catfish Clarias gariepinus fry. Aquaculture, 272, 649-655.

Debnanth, S. (2010). A review on the physiology of insulin like growth factor-I (IGF-I) peptide in bony fishes and its phylogenetic correlation in 30 different taxa of 14 families of teleosts. Advances in Environmental Biology, 5, 31-52.
Effendie, M.I. (1997). Fisheries biology. Yogyakarta: Yayasan Pustaka Nusatama, $163 \mathrm{hlm}$.

Gala, R.R. (1991). Prolactin and growth hormone in the regulation of the immune system. Proc. Sot. Exp. Biol. Med., 198, 513-527.

Habibi, H.R., Ewing, R., Bajwa, \& Walker, R.I. (2003). Gastric uptake of recombinant growth hormone in rainbow trout. Fish Physiology and Biochemistry, 28, 463-467.

Haghighi, M., Sharif, R.M., Sharifpour, I., Sepahdari, A., \& Lashtoo, A.G.R. (2011). Oral recombinant bovine somatotropin improves growth performance in rainbow trout Oncorhynchus mykiss. Iranian Journal of Fisheries Sciences, 10, 415-424.

Handoyo, B. (2012). Respons benih ikan sidat terhadap hormon pertumbuhan rekombinan ikan kerapu kertang melalui perendaman dan oral. Tesis. Institut Pertanian Bogor. Bogor.

Handoyo, B., Alimuddin, \& Utomo, N.B.P. (2012). Pertumbuhan, konversi dan retensi pakan, dan proksimat tubuh benih ikan sidat yang diberi hormon pertumbuhan rekombinan ikan kerapu kertang melalui perendaman. Jurnal Akuakultur Indonesia, 11, 132-140.

Hardiantho, D., Alimuddin, Prasetyo, A.E., Yanti, D.H., \& Sumantadinata, K. (2012). Performa benih ikan nila diberi pakan mengandung hormon pertumbuhan rekombinan ikan mas dengan dosis berbeda. Jurnal Akuakultur Indonesia, 11(1), 17-22.

Harris, J. \& Bird, D.J. (2000). Modulation of the fish immune system by hormones: Mini review. Veterinary Immunology and Immunopathology, 77, 163176.

Irmawati, Alimuddin, Junior, M.Z., Suprayudi, M.A., $\&$ Wahyudi, A.T. (2012). The increase of growth rate giant gourami fry Osphronemus goramy Lac. that immersed with the water containing common carp growth hormone. Jurnal Iktiologi Indonesia, 12, 13-23.

Kelley, K.W. (1989). Growth hormone, Iymphocytes and macrophages. Biochemical Pharmacology, 38, 705-713.

Moriyama, S. \& Kawauchi, H. (1990). Growth stimulation of juvenile salmonids by immersion in recombinant salmon growth hormone. Nippon Suisan Gakkaishi, 56, 31-34.

Moriyama, S., Felix, G.A., \& Hiroshi, K. (2000). Growth regulation by insuline-like growth factor- 1 in fish. Bioscience Biotechnology Biochemistry, 64, 1553-1562.

Pedroso, F.L., Fukada, H., \& Masumoto, T. (2009). In Vivo and in vitro effect of recombinant salmon growth hormone treatment on IGF-1 and IGFBPs 
in yellowtail Seriola quinqueradiata. Fisheries Science, 75, 887-894.

Permana, A., Kusumah, V.R., \& Priyadi, A. (2011). Culture of botia fish Chromobotia macracanthus Bleeker as ex-situ conservation model. Prosiding Forum Nasional Pemacuan Sumber Daya Ikan III. Hasil Penelitian Perikanan dan Kelautan, Bandung.

Promdonkoy, B., Warit, S., \& Panyim, S. (2004). Production of a biologically active growth hormone from giant catfish Pangasianodon gigas in Escherichia coli. Biotechnol Lett., 26, 649-653.

Sakai, M., Kajita, Y., Kobayashi, M., \& Kawauchi, H. (1997). Immunostimulating effect of growth hormone: in-vivo administration of growth hormone in rainbow trout enhances resistance to Vibrio anguillarum infection. Veterinary Immunology and Immunopathology, 57, 147-152. 